INTERNATIONAL JOURNAL OF

\title{
Analysis of Creation Central Agropolitan Through Aglomerative Region Planning in Lampung Province
}

\author{
Iwan Zulfikar \\ Fakultas Ekonomi, Universitas Saburai, \\ Jalan Imam Bonjol No.486, Langkapura Kota Bandar Lampung 35118, \\ Lampung, Indonesia
}

Corresponding author: iwanzulfikar4@gmail.com

\section{ABSTRACT}

Rural areas in Indonesia generally have the potential for agriculture, but there is little industrial sector orientation, especially in the agricultural product processing sector. For this reason, it is necessary to integrate the sectoral and regional planning through the formulation of a development strategy by considering several basic conditions (local potential) so that each stage of development will be clear. Therefore it is necessary to formulate, whether in Lampung Province in the Regency can form a small city by determining the region of the agglomerative hierarchy through the region and the base sector to support the regency agropolitan center. Analyzing is done by using the gravity area method to see regional strength (the strongest regency/city) with an indication of the population, GRDP and also the distance between regencies/cities in Lampung Province. Then to see the strength of the base sector will be done by the LQ method and Input-Output with the expectation of the model used (gravity analysis) that the Agropolitan center can be determined while the LQ and Input-Output models will determine the strength of the "Agro" base sector so that the Regional and Sectoral analysis will the acceleration of regional agglomeration in Lampung Province is seen.

Keywords:

agriculture, agீlomerative region, sectoral and regional planning. 


\section{INTRODUCTION}

The industrialization has been the driving force behind rapid urbanization in the Asian region since the 1980s. Differing in the case of resource-based industries, manufacturing industries tend to be located in and around cities. Agriculture and industry side by side, sometimes even fighting over land around the city center which eventually blurred the standard differences between villages and cities (McGee, 1991).

Industries tend to agglomerate in areas where the potential and ability of an area to meet their needs and benefit from the location of companies that are close to each other. Cities generally offer advantages in the form of higher productivity and income, attract new investment, new technology, educated and skilled workers in far higher amounts than rural areas (Malecki, 1991).

\section{IITERATURF RFVIFW}

For over a hundred years, geographers, economists, urban planners, business strategists, regional scientists and other social scientists have tried to explain "why" and "where" economic activity is located. Inequality of regional distribution of economic activities in one country has become a major concern. This is what drives a lot of research in this field (Kuncoro, 2002).

Development orientation which prioritizes the acceleration of high economic growth more or less can affect the imbalance of development between regions that tend to be urban bias (urban bias) as well as discrimination against rural areas and the agricultural sector. The trickledown effect, which was originally expected to occur, has in part caused an uneven transfer of resources from the rural to the urban areas. The problem is that urbanization almost everywhere in the world is caused by economic development and urban attractiveness, which sometimes traps those who are unable to compete and thus become marginalized. In Indonesia, this development has been very rapid since the 70 s, before that urbanization had also been running but slow and limited. The appeal of the city as a center for livelihoods that is swollen is often coupled and magnified by economic setbacks outside the city and causes those migrants who do not have the skills and ability to compete in urban areas forcing them to be marginalized so that they become poor citizens in urban areas, as unemployment 1999: 43).

In the context of regional development, several development policies continue to evolve as scientific progress and / or the dynamics of the problems encountered. Broadly speaking, these policies can be classified into three groups, namely: (1) development policies from above (Hansen, 1981); (2) development policies from below (Stohr, 1981); and (3) local economic development policies (Blakely, 1991). This agropolitan development area functions as a center of activity and economic growth with an agricultural producing area as a center of agricultural activity (which is generally underdeveloped). The village/person areas with the main activities of the primary sector, because especially agriculture is always faced with low productivity conditions due to several problems including the spread of rural locations and the lack of growth centers in each district economically. Whereas on the other hand, urban areas as market destinations and growth centers always receive excess agricultural production 
materials, even the added value of agricultural products is always outside the area of origin, so to overcome this gap, it is necessary to develop an agropolitan area, especially to sustain areas that have not yet developed or underdeveloped villages. The existence of an agropolitan area with a polar base hierarchy and a Growth Center as a result is formed by the efforts of gravity areas in regencies or cities whose territory accumulates with the title of agslomerates, is expected to become a reference material for regency and city governments in Lampung Province, particularly to spur the regions behind them (from villages to villages). villages spread over several subdistricts) to become a buffer zone for agricultural urban centers.

Moving on from the above, allow to propose an idea with a view to seeing an area in the Regency and City in Lampung Province so that attention in each village and sub-district is fulfilled by the centralization of the region in a hierarchy with the carrying capacity of sectoral and regional aspects so that this region has the ability to compete, both economic competitiveness (and regional competitiveness economic and regional competitiveness).

\section{METHODS}

\section{Problem Identification and Problem Formulation Problem \\ Identification}

From the background as stated above, the problem identification in this study are:

1. Districts and Cities in Lampung Province have not carried out policy directions that strengthen sectoral and regional economic systems, especially in the aspect of village locations scattered along with the population its population and also the distance between villages and between subdistricts especially the regency system of cities based on the size / size of the population and the infrastructure system that supports it.

2. Based on observations not telling and paying attention to regional aspects and also inter-sectoral linkages at the regional level, especially on the aspects of predicate (designation) of Small Cities Whereas they should be as stated in the District and City RPJIMD in Lampung Province, the objectives of the preparation of the RPJIMD are:

a. Providing direction as well as being a reference for all regional components (government, community, and business world) in realizing regional development goals following the vision, mission, and direction of development that is mutually agreed upon.

b. Describe the general condition of the region in the regional constellation, while understanding the direction and objectives to be achieved to realize the regional vision and mission.

3. In the Regencies and Cities in Lampung Province a development policy direction has not yet been formed which focuses on the formation of gravitational areas, especially the relationship of functional relations between the centers of activity in a hierarchical fashion formed by regional infrastructure network systems and regional transportation network systems in the form of primary and secondary systems.

\section{Problem Formulation}

Concerning problem identification as mentioned above, the formulation of the 
problem that the author is trying to say is:

1. Whether in regencies and cities in Lampung Province can be formed agropolitan center.

2. Whether in regencies and cities in Lampung Province, starting from scattered villages and sub-districts, the agglomerative region based on the sector basis can support the/ agropolitan center regency.

3. Whether in Regencies and Cities in Lampung Province with the Regional Planning of the agglomerative hierarchy to support the district / agropolitan regency center, intersectoral linkages can be seen.

\section{Research Objectives}

The purpose of the research conducted in this paper is:

1. Want to find out whether in Regencies and Cities in Lampung Province can be created agropolitan center (City of Agro).

2. Want to know whether in regencies and cities in Lampung Province from scattered villages and sub-districts can determine the region of the agglomerative hierarchy through the base sector to sustain the agropolitan center.

3. Want to know whether in regencies and cities in Lampung Province with Regional Planning the agglomerative hierarchy can sustain agropolitan centers with inter-sectoral linkages.

\section{RFSUITS}

\section{Authenticity and Novelty of Research (Real and a new examiner)}

The agropolitan area is designed to encourage the development of competitive, populist-based, sustainable and decentralized agribusiness systems and businesses that are used and facilitated by the government. While the acceleration of regional development in rural villages can be supported by the creation of agropolitan development areas, this is to answer the problem of regional development disparity between sub-districts of agriculture-based regencies or cities to sustain poles or growth centers that are formed as areas with concentration values.

The existence of an agropolitan area with a polar base hierarchy and a Growth Center as a result is formed by the efforts of gravity areas in regencies or cities whose territory accumulates with the title of agslomerates, is expected to become a reference material for regency and city governments in Lampung Province, particularly to spur the regions behind them (from villages to villages). villages spread over several sub districts) to become a buffer zone for agricultural urban centers. So that in the Regencies and Cities in Lampung Province can be created agropolitan center (Agro City) with the function as an agslomerative region formed through the planning of an agglomeration hierarchy region with inter-sectoral links.

\section{Benefits of Research}

This research is expected to benefit:

1. Regencies and Cities in Lampung Province can create agropolitan centers (Agro Cities)

2. Starting from villages and sub-districts spread out from regencies and cities in Lampung Province can determine the region of the agglomerative hierarchy through the base sector to sustain the agropolitan center.

3. Regencies and Cities in Lampung Province with Regional Planning The 
agglomerative hierarchy can sustain the agropolitan center with inter-sectoral links can be a pioneer in the formation of agropolitan as a rool model for the development of planning areas in Lampung Province.

\section{DISCUSSION}

\section{Analysis Method}

Following the purpose of this study, which is to examine the direction of economic development and the area of Regencies and Cities based on regional potential, the methods and analysis tools used are:

\section{Descriptive Statistics Analysis}

This technique is used to analyze data already available through census, survey or statistical report of the related agency. The analysis is in the form of averages, percentages, comparisons/ratios or rate of change/rate of growth in a certain period. In this study, the use of descriptive statistics is to analyze the physical characteristics of the Regencies and Cities to the Districts through a gravity model to analyze spatial interactions between the sub-districts in the Regencies and Cities, especially human flow analysis. Then to produce the potential of Regency and City Regions that can affect interactions between regions and regional economic characteristics in the form of the growth rate of each economic sector to support the analysis Location Quotient.

\section{The gravity and interaction model of Isaac Newton and Ullman}

This theory assumes that each mass has a gravitational force to interact at each point in the complementary (region regional complementarity), then has the opportunity (intervening opportunity intervening), and ease of transfer or trans- fer in space (spatial transferability). Interaction theory is a theory about the strength of economic relations (economic connection) between two places associated with the population and the distance between these places. The greater the population in both places, the greater the economic interaction. Conversely, the farther the distance between the two places, the smaller the interaction occurs. To use this theory consider the formula in the following figure.

Image (Gravity Formula)

$I_{i j}=k \frac{P_{i} P_{j}}{d_{i j}^{b}}$

Description:

$\mathrm{I}_{\mathrm{ij}}=$ Number of trips between districts and sub-districts

$\mathrm{P}_{\mathrm{i}}=$ Population of districts and subdistricts $i$

$P_{j}=$ Population of districts and subdistricts $j$

$\mathrm{d}_{\mathrm{ij}}=$ Distance between districts and subdistricts $i$ and $j$

= Rank of $d_{i j}$ illustrates the rapid number of trips decreases with distance. The value of $\mathrm{b}$ can be calculated but if not, then what is often used is $b=2$

$\mathrm{k}=$ Constant numbers based on experience, can also be calculated like $b=2$

(Robinson Tarigan, 2012: 149)

\section{Analysis Location Quotient (IQ)}

LQ Analysis Technique is used to identify the sector/commodity base that has a comparative advantage. LQ value is a coefficient number that shows the level of the relative superiority of a regional sector compared to other regions. The LQ coefficient is used to determine the comparative base sector in an area, that is, a 
sector that has reliable potential compared to the surrounding regions.

LQ coefficients range from 0 to infinity positive. An LQ coefficient of less than 1 means that the sector/commodity in question has no comparative advantage. The LQ coefficient is the same as indicating that the sector concerned has the same relative advantage as the average of all regions. LQ coefficient is greater than 1 means that the sector concerned has a comparative advantage that is higher than average.

The approach used is a comparison between the relative function of the GRDP of a sector/production of a commodity in an area with the relative function of the GRDP of a sector/production of a commodity at the regional level above. Thus mathematically, LQ can be formulated with the following equation:

$\mathrm{LQi}=(\mathrm{ei} / \mathrm{e}) /(\mathrm{Ei} / \mathrm{E})$

Note:

LQi = LQ value for sector $\mathrm{i}$ in District / Regency / City analysis

ei = GRDP of sector $\mathrm{i}$ in District / District / City analysis

e = PDRB all sectors in District / Regency / City analysis

Ei $=$ PDRB sector $\mathrm{i}$ in District / Regency / City analysis

$\mathrm{E}=\mathrm{PDRB}$ all sectors in Regency / City analysis

Then the sectors are grouped into four quadrants based on LQ value and the comparative value of the average growth as shown in Figure 1. The leading Sector is the sectors that are in quadrant I, namely the base sector with an average growth above the reference area.

\section{Input-Output Analysis}

It is a comprehensive analysis of the regional economy. In the input-output analysis, an Input-Output table is needed which is a statistical breakdown in the form of a matrix of rows and columns that describe the transactions of goods and services and the linkages between one sector to another. How much the dependence of a sector with other sectors is determined by the amount of input used is achieved if it is not supported by inputs from other sectors. The general framework of the IO table consists of 4 quadrants where each quadrant is expressed in a matrix form, for example, quadrant I with the size of a matrix $(\mathrm{n} \times \mathrm{n})$ shows the number of sectors calculated based on the results of sector qualifications taking into account the potential economic activities of the regional/regional economy.

However, the Multi IO table (MRIO) covers all economic activities. This analysis tool is a study to find out the regional potential in various sectors where the potential which is the content of the regional potential and the potential of the region are interrelated both in terms of forward and backward environment. Or in terms of social review, this Multi IO study is a step to link social and economic studies that actually exist in a space called Kota. These two analytical tools are also correlations of two scientific disciplines that may have never been touched which, although they were actually researched or not examined in an area, actually contained two elements of the study.

For more details can be seen in the Figure 1.

From the Figure "Picture of Matrix Inputoutput Table", can be summarized in the 


\begin{tabular}{|c|c|c|c|c|c|c|c|}
\hline \multirow{2}{*}{ I 0} & \multicolumn{4}{|c|}{ Production Sector } & \multirow[b]{2}{*}{$\mathrm{F}$} & \multirow[b]{2}{*}{$\mathrm{M}$} & \multirow[b]{2}{*}{$X$} \\
\hline & 1 & 2 & $\mathrm{~J}$ & $\mathrm{~N}$ & & & \\
\hline 1 & X11 & X12 & XlJ & Xln & F1 & $\mathrm{Ml}$ & $\mathrm{Xl}$ \\
\hline 2 & X21 & X2え & XえЈ & $x \approx n$ & F2 & M2 & X2 \\
\hline$\cdot$ & . & . & · & . & . & & . \\
\hline . & . & . & . & . & . & . & . \\
\hline i & Xil & Xi2 & $\mathrm{XiJ}$ & & & & $\mathrm{Xi}$ \\
\hline . & . & . & . & Xin. & Fi. & Mi. & . \\
\hline $\mathrm{N}$ & $\dot{x} 1$ & Xn2 & $\dot{x} \cdot \vec{J}$ & $\dot{x n n}$ & Fn & $\mathrm{Mn}$ & $\dot{x n}$ \\
\hline $\mathrm{V}$ & $\mathrm{vl}$ & v2 & v3 & $\mathrm{vn}$ & & & \\
\hline$X$ & $\mathrm{xl}$ & $x 2$ & x3 & $\mathrm{xn}$ & & & \\
\hline
\end{tabular}

Figure 1. Picture of Matrix Input-Output Table

form of general equations like the equation below:

1. Equation by line, $\mathrm{Xi}=\mathrm{xi}+\mathrm{Fi}-\mathrm{Mi}$

$$
\begin{array}{ll}
\mathrm{Xi} & \text { output sector } \mathrm{i} \\
\text { xixi } & \text { number of requests } \\
& \text { between } \\
\text { sector } \mathrm{i} \mathrm{Fi}= & \text { number of final } \\
& \text { requests of } \\
\text { sector } \mathrm{i} \mathrm{Mi}= & \text { import } \mathrm{i}
\end{array}
$$

2. Equation according to column,

$\mathrm{Xj}=\sum \mathrm{xj}+\mathrm{Vj}$

$X_{j}=$ output sector $j$

$x j=$ number of inputs between sectors j

$\mathrm{Vj}=$ number of primary inputs (value added) of sector $j$

Based on Figure 2, two inverse matrices can be derived, namely (IA) - 1 and B (IA) -1 , each of which is a function of the relationship between final demand and output and value-added as follows:

1. $1 . \mathrm{X}=(\mathrm{IA})-1 \mathrm{~F}$

where (IA) - 1 is the inverse matrix of the input coefficient or can also be called an output multiplier matrix used for the development of an inputoutput model
2. $V=B(I A)-1 F$

where $\mathrm{B}$ is a value-added component coefficient matrix.

In this research, the compilation of Regency and City OIs based on Regency and City GRDP in 2018 according to the Use and Business Field issued by the Regency and City BPS. However, because the research area only covers 15 districts and cities, the Regency and City Input-Output table will be reduced to a Multi-DistrictCity Input and Output table supported through the approach Location Quotient (LQ).

The steps to decrease the District InputOutput table into the District and City Input-Output table can be done as follows:

1. Selecting the Input-Output table, because in the Input-Output book consists of three basic tables 14 analysis table which is a decrease in the basic table that illustrates the value of transactions of goods and services between economic sectors. This basic table consists of a total transaction table based on buyer prices, a total transaction table based 
on producer prices and a domestic transaction table based on producer prices. This research uses total transaction table based on producer prices because this table presents a direct relationship between sectors without being affected by transportation costs.

2. Grouping economic sectors, to improve the effectiveness of analysis and based on available data. In this study, a 9-sector Input-Output table or matrix ( $9 \times 9)$ is used.

3. Estimation of the regional InputOutput coefficient using the method Location Quotient (LQ). LQ value $\geq 1$, then the District coefficient value can be directly absorbed as the District and City Region coefficient value, while $\mathrm{LQ}<1$, the coefficient value must be multiplied by the District coefficient number to absorb it as the District and City area coefficient value.

4. Decreased transaction table /table Input-Output, for sectors that have a coefficient value $\geq 1$, the behavior of districts and cities in the IO table can be directly reduced to regional behavior in the District and City IO tables (decreasing behavior is done per column). While sectors that have a coefficient $<1$, transactions are multiplied by regional coefficients.

5. Furthermore, if an area has no input-output analysis yet, the most possible based on cost, time and labor constraints are the non-survey method. There are several nonsurvey methods including the BPS RAS method with the main data used is the provincial IO or Regency and City GRDP. (BPS. 2005. Theory Framework and Analysis of InputOutput Tables)

\section{CONCLUSION}

It is necessary to integrate the sectoral and regional planning through the formulation of a development strategy by considering several basic conditions (local potential) so that each stage of development will be clear. Therefore it is necessary to formulate, whether in Lampung Province in the Regency can form a small city by determining the region of the agglomerative hierarchy through the region and the base sector to support the regency agropolitan center. 


\section{REFERENCES}

Badan Pusat Statsitik Provinsi Lampung, PDRB, 2017

Blakely J, Edward. 1991. Planning Local Economic Development, Theory and Practice. London: SAGE Publication.

Kuncoro, Mudrajad. 2002. Analisis Spasial dan Regional. Yogyakarta: UPP AMP YKPN.

Malecki, E. J. 1991. "Technology and Economic Development: the Dynamics of Local, Regional, and National Change". New York: John Willey \&e Sons, Inc.

McGee, 1991. Water Supply and Sewerage. MCGraw-hill, Inc.

Rencana Pembangunan Jangka Menengah Daerah (RPJMD) Provinsi Lampung, 2015

Robinson Tarigan, 2012, Ekonomi Regional, Teori dan Aplikasi. Edisi Revisi. Jakarta: Penerbit Bumi Aksara. 